\title{
Infrastructure Development and Property Values in Low Income Residential Properties in Bulawayo
}

\author{
Chigwenya Average ${ }^{1}$, Desire Dube ${ }^{2}$ \\ ${ }^{I}$ Department of Landscape Architecture and Urban Design, National University of Science and Technology, \\ Zimbabwe \\ ${ }^{2}$ John Pockock Real Estate, Zimbabwe \\ chigwenyaaver@gmail.com
}

\begin{abstract}
There is a usual positive correlation between infrastructure development and property values. However, in Bulawayo, this correlation does not usually follow in all aspects of properties transactions. This research seeks to find out trends in infrastructure development and property values in the city of Bulawayo. This research took a mixed methods approach in data collection; both qualitative and quantitative methods were utilized. Questionnaires were administered to people in low-income areas of Pumula, Cowdrey Park and Emganwini. Indepth interviews with key informants in the real estate sector were done to cross-fertilize and enrich the inquiry. This research found out that in most cases there is a strong correlation between infrastructure development and property values, but in some cases, there is not any correlation as some forces are put in play distorting the market play. This research also discovered that apart from infrastructure, property values in Bulawayo's lowincome residential suburbs are also affected by income, supply, and demand factors.
\end{abstract}

(C) 2018 IJBESR. All rights reserved.

Keywords: Infrastructure development, property values, property market, valuation

\section{Introduction}

Property values differ with the type of uses, the kind of available infrastructure, the age of buildings, and the socio-economic environment that is prevailing in the area in which the property is located. Among all these factors, infrastructure plays a very critical role in determining property values. Without infrastructure, the land is just void and lacks value. According to Mills, without sewer, water and electricity, the land is just a skeleton and have no value. Such properties fetch shallow values in the market because they are usually regarded as unplanned, and they also do not give people the desired intrinsic values. Properties that are endowed with proper infrastructure provision have good accessibility, and this has positive externalities in terms of boosting their benefits in the market.
Zimbabwean cities have in the recent past been witnessing a rapid an uncontrolled urban development, and this had created a severe problem in the property market. This unprecedented move has created market distortions. This study tries to unearth some of the market distortions that have been created by these developments.

\section{An Inventory of Infrastructure Facilities in Bulawayo's High-density Areas}

There are infrastructural disparities that are found in the high-density suburbs of Bulawayo. In some areas (Enganwini, Pumula and the other part of Cowdrey Park) there is a proper provision of infrastructure ranging from right tarred roads to supporting institutions such as schools, churches, and commercial services. These areas are also endowed with good water, 
sewerage, and electricity supply. However, residents in these areas think that it will be good for them if this infrastructure is well maintained. Maintenance is one of the factors that is disadvantaging these areas because frequent sewer burst often put residents at risk of contracting water-borne diseases. Table 1 below shows infrastructural provisions that are commonly found in most of the high-density suburbs of Bulawayo.

Table 1: Infrastructural facilities in most high-density suburbs of Bulawayo

\begin{tabular}{|l|l|}
\hline Infrastructure & General comment \\
\hline Tarred roads & $\begin{array}{l}\text { Poorly maintained with pot } \\
\text { holes }\end{array}$ \\
\hline Gravel roads & Eroded by water \\
\hline Electricity & $\begin{array}{l}\text { Available through load } \\
\text { shedding }\end{array}$ \\
\hline Reticulated water & Available through rationed \\
\hline Reticulated sewer & $\begin{array}{l}\text { Available through some are } \\
\text { aged and there is frequent burst }\end{array}$ \\
\hline $\begin{array}{l}\text { Primary and secondary } \\
\text { schools }\end{array}$ & Available and at good distance \\
\hline Clinics & Available and at good distance \\
\hline Proper shopping facilities & Available and at good distance \\
\hline
\end{tabular}

Source: Authors' survey, 2018

However, there are other places such as the one that was targeted by the Operation Restore Order/Operation Murambatsvina, which was a government program meant to get rid of all informal settlement in all urban areas. The operation left more than 1.4 million people without houses [1]. The government then went on to parcel out land to the affected people so that they could build their homes. These settlements are however poorly serviced as they lack essential services for human habitation. The areas do not have proper roads as the roads servicing these areas are just rough roads that are not even graveled (see figure 1 below). They do not have water reticulation, and most of the residents are getting their water from shallow wells and communal boreholes. Their commercial areas are just tuck shops, which are small informal traders that are servicing the areas. These structures are also not permanent; they are only temporary structures made out of temporary materials such as wood and plastics (see figure 1 below). If these people want more commercial services, they have to walk more than five kilometers to the nearest supermarket, but some residents have to travel double that distance because they are located further away from these commercial services.

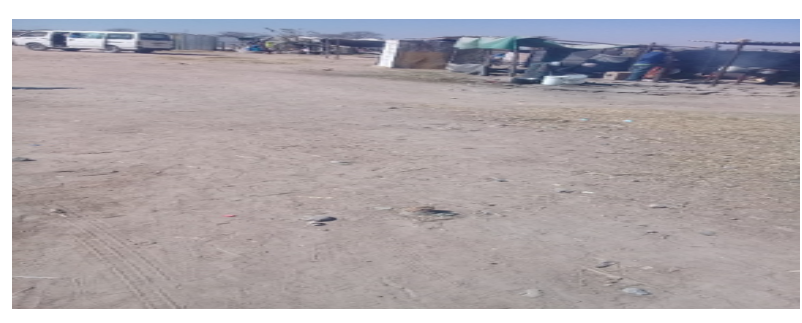

Source: Authors' survey, 2018

Figure 1: The make-shift store and the roads in Cowdrey Park

The sewerage system does not exist in these areas as either eco-san toilets or Blair toilets servicing the houses. However, the city authorities are planning to come in to provide such essential infrastructure. The Blair toilets are a potential threat to the health system of the city because in rainy seasons they flood, thereby posing a potential threat to the contamination of groundwater. While the ecosan toilets are said to be environmentally friendly sanitation system, there is a need to monitor how they are treated so that they do not contaminate the environment. There are no schools in the area as people have to seek these services from nearby locations. This condition forces school children travel more than 10 kilometers to the nearest school. Table 2 below shows the infrastructure that is on the other side of Cowdrey Park and the general comments from the public.

Table 2: Type of infrastructure and the general public comments

\begin{tabular}{|l|l|}
\hline Infrastructure & General comment \\
\hline Tarred roads & No tarred roads \\
\hline Gravel roads & $\begin{array}{l}\text { Roads not gravelled they are just } \\
\text { bush roads }\end{array}$ \\
\hline
\end{tabular}


International Journal of Built Environment and Scientific Research

\begin{tabular}{|l|l|}
\hline Electricity & $\begin{array}{l}\text { No power people are using fire } \\
\text { wood }\end{array}$ \\
\hline Reticulated water & $\begin{array}{l}\text { Communal boreholes and } \\
\text { shallow wells. }\end{array}$ \\
\hline Reticulated sewer & Eco-san toilets and Blair toilets \\
\hline $\begin{array}{l}\text { Primary and secondary } \\
\text { schools }\end{array}$ & No schools \\
\hline Clinics & No clinics \\
\hline Proper shopping facilities & Only tuck shops \\
\hline
\end{tabular}

Source: Authors' survey, 2018

The infrastructural deficiencies in the Cowdrey Park section make their life so difficult as they walk long distances to the nearest conventional shops and in search of health facilities. The nature of the roads is such that most of the transport operators shun this place and those that service the areas are too expensive. The situation is horrible in the rainy season because the transport operators stop plying the area because of poor road infrastructure.

\section{Property Sales in High-density Residential Suburb of Bulawayo: A Comparative Study}

Property values are a reflection of the interplay of various factors that include the environment, age of the buildings, and the size of the buildings [2]. In a correctly functioning market, the value of the property is a function of market interplay where potential buyers or tenants outbidding each other to obtain ownership or possession of the property. Infrastructure also plays a significant role in determining property values. According to Frischmann [3], the user is willing to pay higher prices for property which is properly endowed with infrastructure because they can derive more benefits from the infrastructure provided. Thus, infrastructure development has positive externalities on property values. Figure 2 below shows the property values of infrastructure-endowed areas (Nkulumane, Pumula, and Emganwini) and property values of poorly endowed residential areas (Cowdrey Park). Residential areas with good infrastructure are fetching better benefits than those in poorly serviced

areas. Properties from these areas are the one preferred in the market and they dominate their sales outputs. Figure 2 below compares property sales in different high-density residential regions in Bulawayo. Nkulumane areas is the area that is leading in property sales in the high-density suburbs of Bulawayo because this area has excellent infrastructure, including tarred roads in good condition and has a massive shopping complex that is servicing most of the suburbs in this southern region of the city. Other areas with proper infrastructural development are also doing reasonably well in property sales, including Emthunzini (21\%), Lavender (20\%), Pumula, and Emganwini, though have aging infrastructure are also commanding a significant share. However, poorly serviced areas of Cowdrey Park have a meager share in the property market $(3 \%)$. At the Nkulumane shopping complex, several services are offered at that, making a significant node in terms of service provision in the areas. The residential area is also housing district offices for the city of Bulawayo, thereby offering an administrative function for the areas around.

\section{Chart Title}

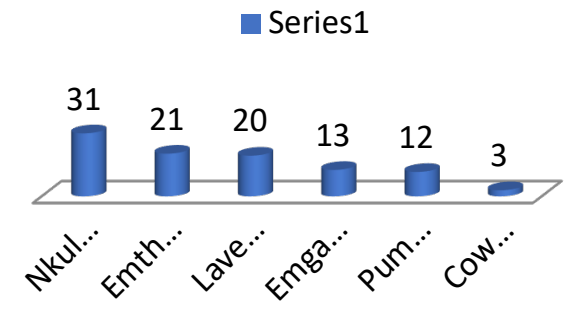

Source: Average and Dube, 2018

Figure 2: Property sales in different residential areas of Bulawayo

Pumula and Emganwini recorded relatively low outputs in terms of property sales. This can be attributed to the nature of infrastructure in these areas. Pumula has aging infrastructure. Emganwini is a reasonably new suburb whose infrastructure is still under construction, so 
people prefer areas with properly developed infrastructure than those that are aged and those that are still under construction. Residents in this area are complaining about frequent sewer burst and unattended gravel roads, which are characterized by severe erosion and potholes. Cowdrey Park is the residential area with deplorable infrastructure as alluded above. There are no proper roads, power is not installed, and sewer and water reticulation systems are not connected. These areas, therefore, are performing very poor in terms of sales of the property in the city. It is only constituting $(3 \%)$ of property sales in the highdensity suburbs of Bulawayo.

Infrastructure resources are intermediate goods that create social value and are significant factors in the production systems of the city [3][4]. Famuyiwa and Otegbulu [4] further argued that infrastructure provides multidimensional benefits that impact positively on property values. Its economic function to lubricate the wheels of development and improves the wellbeing of humanity, according to them, cannot be viewed in isolation of the environment that surrounds it. It is the totality of context and the quality of the neighborhood. Infrastructure, therefore, can be utilized productively downstream, and such use is the primary source of social benefits. These social benefits are the most sought after values when people are looking for properties. Therefore, according to Famuyiwa and Otegbala [4], housing values tend to keep in those locations that enjoy infrastructure development. According to Harvey [5], people are prepared to pay high prices for properties that are adequately serviced with excellent infrastructure. Infrastructure, therefore, has positive externalities on property values as its presence leads to the appreciation of property values [6]. He further argued that good infrastructure gives efficiency in human activities and all these attributed lead to the appreciation of property values. Infrastructure can play a significant role in the transformation of localities because infrastructure can be used as conduits for transforming resources into outputs, which will change the outlook of locations. As they change, they will be functioning more efficiently and enabling more economic activities that will lead to growth and appreciation in property values. In a survey that was done on real estate experts in Bulawayo, the researcher discovered that the availability of infrastructure in an area influences decision on the location of property acquisition.

Areas that are well endowed with infrastructures such as water, electricity, transport, and sewer are more valuable than those without. Transport infrastructure plays a significant role in improving the accessibility of the areas. As places are more accessible, they attract more traffic volumes, and as the traffic volumes increase rental of such location are likely to be increased [7]. Areas with good infrastructure are therefore on high demand as people will be competing to access such properties. Such competition thus pushes prices of their properties up [4][5][8]. Mikelbank [7] further argued that properties that are located near a major highway are more valuable than those that are further away from the major arteries of the city.

Lack of infrastructure in Cowdrey Park is, therefore, the chief cause of the lowest property sales transactions in Bulawayo. These locations turn to lose many potential property buyers due to negative externalities that are associated with such properties. Lack of functional shopping area, poor roads, and lack of essential infrastructure for essential services such as water, electricity, and sewerage are the contributing factors for weak preferences for properties in the Cowdrey Park.

According to the survey, it was obtained that most property buyers in the city of Bulawayo are looking for properties that can satisfy their needs and this is shown by the infrastructure that is associated with the residential areas. Responses obtained from $93.8 \%$ of real estate 
experts indicated that residential property buyers prioritize together with the property selling price when selecting a property to buy in Bulawayo. According to Salu-Kasoko et al. [8], real value in real estate is predicated on the available infrastructure; properties without infrastructure have therefore no value because it has low or no utility to the potential buyers. Real estate has significance only as it satisfies man's needs and desires. It can be argued that real estate can only meet man's needs if it has a reticulated sewer and water system, electricity, schools, health and shopping facilities, and an accessible road network. Such properties are more attractive, and their demand is high, which create a bidding process that pushes their prices up [9-11].

\section{Property Values in High-density Residential Areas in Bulawayo}

Properties in the residential areas show a range of price that ranges from $\$ 12,000.00$ to $\$ 25,000.00$, showing an average price of $\$ 18,500.00$. This is the price of a four-roomed house in the city's high-density suburbs. This price range is obtained in the all high-density suburbs irrespective of the nature of infrastructure in the area. The price is, therefore, varies based on the general conditions of the property, where those properties that are better maintained will fetch higher rates than those that are poorly maintained. Even properties in the poorly serviced areas of the Cowdrey Park are fetching prices that are matching those of the betterserviced areas of Emganwini, Pumula, and Nkulumane. In Nkulumane there is the best infrastructure in the high-density suburbs with right tarred roads and a well-developed shopping complex offering different commercial services such as banking, furniture, and grocery shops. A four-roomed house in Cowdrey Park, which is poorly serviced can fetch as high as $\$ 18000$, which is the same sales value of a similar four-roomed home, in Pumula and Emganwini. These price similarities show that there are other factors other than infrastructure that is a place to determine prices of properties.

Elements of supply and demand are likely to produce such market trends because the market will be so bottle-necked in terms of the amount so that people will be competing for the few available properties. According to Kiara in Namibia, these factors of supply and demand are responsible for driving property prices upwards irrespective of the nature of the available infrastructure. The other factor is that the property owners are taking advantage of the shortages in the property market and are, therefore, selling their properties at cost prices. They are basing their values on the cost of constructing the property. This however is contrary to the dictates of the valuation theory, which states that property values are not the same as the cost of construction. A property value can be defined as the amount obtained in a sales transaction between a willing and able purchaser and a willing seller, for a particular property and at a specific time in an informed market. This implies that for any property sale, the property seller should first accept the value offered by the purchaser, for a sales transaction to be concluded. By allowing a sales value provided by a purchaser, property sellers are not only setting the sales value but are also validating property values. People in these areas are therefore selling the properties to recover their costs of the building. This, again, violates the valuation theory. In valuation, theory location plays a very critical role in determining property values. Different places have different characteristics and different values depending on the nature of the place. Most of the locations in the study areas are adequately endowed with excellent infrastructure in terms of right roads and other facilities. In Cowdrey Park, the neighborhoods, the city is scantly serviced and the streets are poorly developed. Most of the streets are bushy, and transport operators are shunning the areas, especially during the rainy season; hence the area has poor connectivity. However, properties 
in these areas are fetching values that are close or similar to those areas which have proper infrastructure development. According to Mikelbank [7], locations that correctly service with roads have better connectivity and accessibility. This creates demand for properties in such areas and hence their values for both rental and capital values are generally higher than those. He further argued that such features with high connectivity are the most preferred by households and they are therefore prepared to pay high values for such properties. He also noted that properties that are further away from main transport arteries tend to drop their values by $2.3-3.8 \%$ as the distance increases from these transport infrastructures. A proper infrastructure provision provides efficiency in human activities and positively impacts on the standard of living and economic growth. This, therefore, creates some positive externalities such as high standards of living and more top prospects for economic growth. Such positive externalities are highly sought after when one is looking for properties; hence, it pushes the property values higher [12]. He further argued that a proper infrastructure provisioning has a transformative effect because it helps in transforming resources into outputs and such impacts are highly sought after when people are looking for accommodation. Nubi [13] also argued that infrastructure provisioning is a critical factor that weighs heavily on property values because infrastructure provisioning allows cities to function correctly by enabling economic growth and enhancing a high quality of life. He further argued that infrastructure is a critical component in real estate as it brings in personal satisfaction. In his assessment, the property has no value if it has no utility and utility can only be achieved if the property has the infrastructure. It can be argued that the condition of the house substantiates the rationale behind construction cost recovery in the event of a successful property sale. It is important to note that the demand for housing in the city of Bulawayo far outstrip the supply such that when it comes to buying properties, the market is short supplied such that customers compete for the available stock of housing units. Bulawayo's housing waiting list is standing at 110,000 according to the Government of Zimbabwe [14], and this situation is obtaining against the background of inadequate supply of housing units for lowincome groups in the city. The city is only able to provide 3,000 stands per year, but they have been failing to offer such positions for the previous years because of economic difficulties that the country has been facing. The city is therefore incapacitated to provide serviced stands in the town, which has again pushed the price of unserviced positions by close to $33 \%$. For example, a 200 square meter stand was going on average for $\$ 17.00 / \mathrm{m} 2$, and it has now risen to $\$ 22.50 / \mathrm{m} 2$.

A comparison of prices of stands in areas with infrastructure and areas with none shows that there is a marginal difference in their rates. For example, a serviced stand of $200 \mathrm{~m} 2$ in the high-density residential regions in Emganwini cost $\$ 4,500.00$, and an unserviced position in Cowdrey Park is marginally lower at $\$ 3,500.00$. Stands in the Cowdrey Park are virtually undeveloped without any services such as water, roads, electricity, and sewer, but they are prices are a mere $25 \%$ less than the cost of serviced stands. It shows that the impact of infrastructure on property values is minimal, and therefore, there should be other factors that are heavily influencing the prices of properties in these areas. In the Cowdrey Park area, people have no reticulated water or sewer; people are fetching water from shallow wells and communal taps. They are using Blair toilets and eco-san toilets, but their prices are fairly comparing with those of areas in properly serviced areas. The city has no schools, clinics, or shops, and they are not serviced by a good transport system, but these deficiencies are not adequately reflected in their prices. Prices of the properties should be a reflection of the services that are offered in the area, these services 
should drive the satisfaction that these properties give to their owners, and such comfort should push them to pay more for them. However, the situation in Bulawayo's high-density suburbs in general and Cowdrey Park, in particular, does not follow this logic. People are prepared to pay relatively high prices for poorly serviced areas and in some cases, people are living with virtually no services [5][15][16]. They are complaining that they are living a life that is divorced from urbanity since their communities resemble rural communities because of poor services that are offered in the area. Aibangbee [16] further argued that a proper infrastructure provision reduces the cost of doing business, which in turn increased the profitability levels of industrial activities in the area.

However, there is a marked difference that is shown in rental values between areas with excellent infrastructure and those without. The rentals are showing pronounced differences which show a marked influence of infrastructure on rental costs. In regions of Cowdrey Park, which is poorly serviced area, the average rentals for a four-roomed house are $\$ 78.00$. In Cowdrey Park some poorly maintained properties are fetching as low as $\$ 40.00$ per month; these are usually those properties that are still under construction. The same size of the property is calling for a rental $\$ 250.00$ per month in areas with good infrastructure such as Emganwini, Pumula, and Nkulumane. Rentals have jumped more than three times in the properly serviced areas than those. According to Salu-Kasoko et.al. [8], properties in the regions that are well endowed with excellent infrastructure such as piped water, and sewer often fetch higher rentals compared to areas without because people are prepared to pay for services that are offered in the regions rather than staying in the areas that are severely constrained due to poor infrastructure provisions. Studies were done by Acevedo et al. [17] in Campo Grande, Brazil, showed that there are noticeable changes in housing prices when areas are provided with urban infrastructure showing a positive correlation between infrastructure provision and property values. Regression analysis in this research also showed that there is a positive correlation between infrastructure development and property values. A coefficient of 1.000 was found in areas such as Pumula South, Cowdrey Park, and Emganwini in both property values and rental values. Pan et al. [18] observed that the introduction of rail transit lines on residential property values in Shanghai introduced positive externalities on properties affected. According to Arnold et al. [19], property values in South Africa are also affected by factors such as household incomes, which are also determined by affordability and accessibility of property finance. Even studies by Lombard et al. [20] in Pretoria and Johannesburg showed that there is a positive correlation between property values and infrastructure development because property values are appreciated due to the introduction of train stations in these cities. According to Rosato et al. [21], mobility in residential areas is essential as it determines accessibility in the area, and this makes areas with such infrastructure good neighborhood. However, Tsatsaronis and Zhu [22] added another factor such as availability of land and construction cost also as playing a significant influence on property values and rental values. Ajibola et al. [12] also added that there is a meaningful statistical relationship between land use planning and property values.

Although there is a general perception that there are other factors such as income levels, fluctuation of foreign exchange rates and the current economic environment at play in determining the property values, the influence of infrastructure provision has proved to be a substantial factor in determining the property and rental costs. Foreign currency in Zimbabwe is mostly available on the parallel market, and this has brought a lot of instability in the economy, and this is also reflected in the 
property market. The majority $(75 \%)$ of the respondents, however, think that infrastructure provision has a strong bearing on property values. According to studies done in Nigeria infrastructure development by Bello and Olujimi [23], properties that are correctly endowed with excellent infrastructure have higher costs because infrastructure contributes significantly to the development of the property. They concluded that it is generally believed that the provision of infrastructure in residential property would continue to attract prospective tenants. Augustine [26] argued that Nigeria established a 0.905 positive correlation between property values and available infrastructure development.

\section{Conclusion}

Housing cannot be fully examined in isolation of the ancillary uses that are associated with it. The provision of such purposes improves significantly on the values of the property. In Bulawayo, this research has shown that there is a strong correlation between infrastructure provision and property values. It shows that infrastructure provision has positive externalities on property. People in the city of Bulawayo also indicated that they preferred features in infrastructure-endowed areas as these properties are highly sought after and they don't take time on the market. However, on the prices of property in the high-density areas, infrastructure has shown to have a minimal effect because there is a marginal difference between features in the infrastructure-endowed areas and in those high-density areas. It indicates that other factors come strongly on that. It can be attributed to the supply system in the city. The high demand for properties and the bottlenecked supply system are the pointers to that behavior. Since people have no alternative in terms of other sources of supplies, they have to rely on the few available properties. Since there are few properties in the market, they are priced almost the same those in robust infrastructure-endowed areas and those with inadequate infrastructure provision. The city council is still battling to supply adequate housing because there are a lot of people registered on the housing waiting list.

Infrastructure also showed that it is a critical component in influencing rental values in the high-density areas of Bulawayo because it has proved to be a substantial factor in influencing rental vales. In areas that have no or inadequate infrastructure, the rental values have shown to be very low; in some case half and in other cases a third the benefits of those areas with proper infrastructure provision.

\section{References}

[1] Potts D. The urban informal sector in Sub-Saharan Africa: From bad to good (and back again). Development Southern Africa. 2008:25(2); 151-162.

[2] Oloke OC, Simon RF, Adesulu AF. An examination of the factors affecting residential property values in Magodo neighbourhood, Lagos state. International Journal of Economy, Management and Social Sciences. 2013:2(8).

[3] Frischmann BM. An Economic Theory of Infrastructure and Commons Management. Minnesota Law Review; 2005.

[4] Famuyiwa F, Otegbulu A. Public water infrastructure in property prices: An environmental evaluation approach. Elixir Infrastructure Management. 2012;51:11034-11038.

[5] Harvey J. Urban Land Economics. London: Macmillan; 1993.

[6] Ajibola, MO, Awodiran OO, Salu-Kosoko O. Effects of infrastructure and property values in Unity States Lagos. International Journal of Economy, Management and Social Sciences. 2013;5:195-205.

[7] Mikelbank BA. Spatial analysis of relationship between housing values and investment in infrastructure. Analysis of Regional Sciences. 2004:38;705-726.

[8] Salu-Kasoko O, Ajibola MO, Awodiran OQ. Effects of infrastructure on property values in Unity Estate, Lagos, Nigeria. International Journal of Economy, Management and Social Sciences. 2013:2(5).

[9] Debrezion G, Pel E, Rietveld P. Impacts of railway station on residential and commercial property values: A meta-analysis. Journal of Real Estate, Finance and Economics. 2007;35:165-180.

[10] Harmmer L, Booth D, Love HE. Poverty and transport. Report prepared for World Bank in Collaboration with DFID. London: ODI; 2000.

[11] Hensher AD, Li Z, Mulley C. The impact of high speed rail on land and property values: A review of market monitoring evidence from eight countries. Road and Transport Research. 2012;21(4):3-14.

[12] Ajibola MO, Oluwunmi AO, Eguho. Examining the factors contributing to affordable housing in Kosofe Local Government Council area, Lagos, Nigeria. Journal of Asian Business Strategy. 2012;2(10). 
[13] Nubi TO. Procuring, managing and financing urban infrastructure. towards integrated approach. Presented at National Working on Land Management and Property Tax Reform in Nigeria. 2002.

[14] Government of Zimbabwe. Regional Town and Country Planning Act. Harare: Printflow (Private) Limited; 2013.

[15] Harvey J, Jowsey E. Urban Land Economics. $6^{\text {th }}$ ed. London: Plagrave Macmillan; 2004.

[16] Aibangbee SS. Functions of urban infrastructure in national development. Presented at the $27^{\text {th }}$ Annual Conference of Nigerian Institute of Estate Surveyors and Valuers, Premier Hotel, Ibadan 1-6 April 1997.

[17] Acevedo P, Hobbs AJ, Martinez S. The Impact of Upgrading Municipal Infrastructure on Property Prices: Evidence from Brazil. $1^{\text {st }}$ ed. Washington, DC: InterAmerican Development Bank; 2017.

[18] Pan Q, Pan H, Zhang M, and Zhong B. Effects of rail transit on residential property values: Comparison study on the rail transit lines in Houston, Texas and Shanghai, China. Transportation Research Record. 2453; 118-127. DOI 103141/2453-15

[19] Arnold K, Roux A, Hattingh M. impact of Gautrain stations on property prices and sales activity in the city of Johannesburg between 2006 and 2015. South African Journal of Geomatics, 2017;6(2).

[20] Lombard S, Behrens R, Virully F. Value creation around transport infrastructure in South Africa: The case of Gautrain. 36th Southern African Transport Conference (SATC 2017). 2017.

[21] Rosato D, Breil M, Cuupponi C, Berto R. Assessing the Impact of Urban Improvements on Housing Values: A Hedonic Pricing and Multi-Attribute Analysis Model for the Historic Centre of Venice. Venice, 2017.

[22] Tsatsarinos K, Zhu H. What drives housing prices dynamics: Cross-Country evidence. BIS. 2004:March.

[23] Bello MO, Olujimi JAB. Effects of infrastructural facilities on the rental values of residential property. Journal of Social Sciences. 2009;5(4).

[26] Augustine JK. The Developments in Real Estate and Sustainable Urban Environment: A Case Study of Kilimani Area within Nairobi City County. Research Project of Master Degree in Valuation and Property Management. Nairobi: School of The Built Environment, University of Nairobi; 2016 
- This page is intentionally left blank - 